\title{
Study on the Content and Influence of Heavy Metal Elements in Dust of Xiqing District of Tianjin
}

\author{
YanShan $\mathrm{Yin}^{1}, \mathrm{Jin} \mathrm{Xu}^{2 *}$ \\ ${ }^{1}$ Safety engineering, School of Environmental Science and Safety Engineering, Tianjin University of Technology, 300380, Tianjin, China \\ ${ }^{2}$ Environmental engineering, School of Environmental Science and Safety Engineering, Tianjin University of Technology, 300380, \\ Tianjin, China
}

\begin{abstract}
At present, heavy metal elements in dust have great influence on air quality and human health,therefore, the content and influence of heavy metal elements on campus were studied. Firstly, PM10 and total dust in the autumn campus atmosphere were sampled for 10 consecutive days, and then digested by electric heating plate digestion method. Then, inductively coupled plasma emission spectrometer (ICP-OES) was used to detect and analyze the content and concentration ratio of seven heavy metal elements $\mathrm{Cu}, \mathrm{Pb}, \mathrm{Cd}$, $\mathrm{Zn}, \mathrm{Cr}, \mathrm{Hg}$ and $\mathrm{Ba}$ in PM10 and total dust. Finally, through comparative analysis, it is concluded that heavy metal pollutants in the atmospheric environment are mainly $\mathrm{Zn}$ and $\mathrm{Ba}$, and the concentrations of $\mathrm{Cd}, \mathrm{Zn}$ and $\mathrm{Ba}$ are seriously exceeded, so the air quality in Xiqing District of Tianjin is poor, and the particle size distribution of $\mathrm{Cd}$ and $\mathrm{Hg}$ makes it easy to enter the human body, which is especially unfavorable to human health.
\end{abstract}

\section{Introduction}

\subsection{Research background}

In recent years, heavy metals in dust have gradually become the focus of research. Heavy metals in dust have a great impact on human health,however, the environmental quality standards for atmospheric dustfall have not yet been established in China,although dust and heavy metals have been studied in depth, the research on heavy metals in dust is almost blank, and the relevant evaluation indexes for air conditions are various, and few heavy metals in dust are included in the evaluation indexes. By comparison at home and abroad, it can be found that the average content of heavy metals in atmospheric deposition in China is generally higher than that in foreign countries. This may be related to China's current economic development level, industrial development structure and local value of heavy metals in soil. With the gradual improvement of economic level, society pays more attention to health,it can be predicted that heavy metals in dust will become a hot research target.

\subsection{Research status at home and abroad}

(1) Experimental basis

Existing laboratory instruments are adopted, including TSP for PM10, FC-3 for total dust and ICP-OES for detection.

(2) Research methods

Content of heavy metal elements in filter membrane samples are inductively coupled plasma mass spectrometry (ICP-MS) ${ }^{[1]}$, emission spectrometry (ICPAES) ${ }^{[2]}$, ion chromatography ${ }^{[3]}$ and atomic absorption spectrometry (AAS) ${ }^{[4]}$.

Generally speaking, the current research on heavy metals in dust has attracted wide attention from the society and academic circles, and the research results from various perspectives in academic circles are rich and colorful, but the research on heavy metals in campus areas is still blank, therefore, this paper compares the concentrations of heavy metals in inhalable particles (PM10) and total dust to explore their harm to human body.

\section{Experiment of heavy metal elements in dust}

Dust is divided into respirable dust and total dust,PM10 and total dust were investigated by experimental method.

\subsection{Dust heavy metal sampling}

According to the literature, it is found that the dust heavy metals in atmospheric deposition mainly include $\mathrm{Cu}, \mathrm{Pb}$, $\mathrm{Cd}, \mathrm{Zn}, \mathrm{Cr}, \mathrm{Hg}$ and $\mathrm{Ba}$. These dust and heavy metals which have been studied at present have caused great harm to human health. Therefore, this experiment mainly samples and detects the above seven heavy metal elements.

\subsubsection{Sampling place and time}

(1) Sampling location

The sampling site is chosen at the entrance of East

\footnotetext{
${ }^{*}$ Corresponding author: xujinhb@email.tjut.edu.cn
} 
Fifth Gate of Tianjin University of Technology, which is typical and representative, with both large flow of people and surrounding traffic nearby.

(2) Sampling time

Sampling conditions such as sampling time and flow rate are shown in Table 1 .

Table 1. Dust sampling status.

\begin{tabular}{cccc}
\hline Dust type & $\begin{array}{c}\text { Sampling } \\
\text { time }\end{array}$ & $\begin{array}{c}\text { Sampling } \\
\text { flow }\end{array}$ & $\begin{array}{c}\text { Sampling } \\
\text { times }\end{array}$ \\
\hline
\end{tabular}

\begin{tabular}{cccc}
\hline $\begin{array}{l}\text { Total dust } \\
\text { Inhalable } \\
\text { particles }\end{array}$ & $90 \mathrm{~min}$ & $5 \mathrm{~L} / \mathrm{min}$ & $\begin{array}{c}1 \text { time per } \\
\text { day } \\
1 \text { time per } \\
\text { day }\end{array}$ \\
\hline
\end{tabular}

(3) Sampling meteorological conditions and results This sampling is carried out under the normal conditions of Tianjin University of Technology and the corresponding environmental standards (standard volume), after 10 days of instrument sampling, the dust sampling results can be obtained, as shown in Table 2 .

Table 2. Meteorological conditions and results of dust sampling.

\begin{tabular}{|c|c|c|c|c|c|c|}
\hline $\begin{array}{c}\text { Sampling } \\
\text { time }\end{array}$ & Temperature $/{ }^{\circ} \mathrm{C}$ & $\begin{array}{c}\text { Air pressure } \\
\text { /KPa }\end{array}$ & $\begin{array}{l}\text { Air quality } \\
\text { PM10 }\end{array}$ & $\begin{array}{l}\text { Weather } \\
\text { conditions }\end{array}$ & $\begin{array}{l}\text { Sample } \\
\text { number }\end{array}$ & $\begin{array}{l}\text { Sampling } \\
\text { volume / } \mathbf{L}\end{array}$ \\
\hline \multirow{2}{*}{9.12} & \multirow{2}{*}{29.5} & \multirow{2}{*}{101.1} & \multirow{2}{*}{84} & \multirow{2}{*}{ Cloudy } & $\mathrm{z}-01$ & 450 \\
\hline & & & & & $\mathrm{h}-01$ & 33294 \\
\hline \multirow{2}{*}{9.13} & \multirow{2}{*}{22} & \multirow{2}{*}{101.0} & \multirow{2}{*}{85} & \multirow{2}{*}{ sunny } & $\mathrm{z}-02$ & 450 \\
\hline & & & & & $\mathrm{h}-02$ & 33692 \\
\hline \multirow{2}{*}{9.14} & \multirow{2}{*}{22} & \multirow{2}{*}{101.6} & \multirow{2}{*}{112} & \multirow{2}{*}{ Cloudy } & $\mathrm{z}-03$ & 450 \\
\hline & & & & & h-03 & 28132 \\
\hline \multirow{2}{*}{9.15} & \multirow{2}{*}{25.5} & \multirow{2}{*}{101.5} & \multirow{2}{*}{15} & \multirow{2}{*}{ Cloudy } & $\mathrm{z}-04$ & 450 \\
\hline & & & & & h-04 & 30459 \\
\hline \multirow{2}{*}{9.16} & \multirow{2}{*}{19} & \multirow{2}{*}{102.3} & \multirow{2}{*}{21} & \multirow{2}{*}{ Cloudy } & $\mathrm{z}-05$ & 450 \\
\hline & & & & & h-05 & 29141 \\
\hline \multirow{2}{*}{9.17} & \multirow{2}{*}{25.5} & \multirow{2}{*}{101.6} & \multirow{2}{*}{43} & \multirow{2}{*}{ Cloudy } & $\mathrm{z}-06$ & 450 \\
\hline & & & & & h-06 & 30000 \\
\hline \multirow{2}{*}{9.18} & \multirow{2}{*}{21} & \multirow{2}{*}{101.3} & \multirow{2}{*}{52} & \multirow{2}{*}{ sunny } & $\mathrm{z}-07$ & 450 \\
\hline & & & & & h-07 & 30431 \\
\hline 010 & 16 & 1012 & 56 & Cloudv & $\mathrm{z}-08$ & 450 \\
\hline 9.19 & 16 & 101.2 & 56 & Cloudy & h-08 & 30145 \\
\hline 920 & 24 & 1008 & 57 & Cloudv & $\mathrm{z}-09$ & 450 \\
\hline & & & & Cloudy & h-09 & 31000 \\
\hline 021 & 20 & 1006 & 33 & sunny & $\mathrm{z}-10$ & 450 \\
\hline 3.21 & 20 & 100.0 & 53 & summy & $\mathrm{h}-10$ & 27304 \\
\hline
\end{tabular}

\subsubsection{Sampling equipment and methods}

The equipment and methods used in this experiment are shown in Table 3 .

Table 3. Sampling 3 Equipment and Method.

\begin{tabular}{|c|c|c|c|}
\hline Test item & $\begin{array}{l}\text { Method of } \\
\text { sampling }\end{array}$ & $\begin{array}{l}\text { Sampling } \\
\text { equipment }\end{array}$ & $\begin{array}{c}\text { Analytical } \\
\text { method }\end{array}$ \\
\hline Total dust & $\begin{array}{l}\text { Enrichment } \\
\text { method } \\
\text { with dust } \\
\text { filter } \\
\text { membrane }\end{array}$ & $\begin{array}{l}\text { FC-3 dust } \\
\text { sampler }\end{array}$ & $\begin{array}{l}\text { Weight } \\
\text { method }\end{array}$ \\
\hline $\begin{array}{l}\text { Inhalable } \\
\text { particles } \\
\text { (PM10) }\end{array}$ & $\begin{array}{l}\text { Enrichment } \\
\text { method } \\
\text { with dust } \\
\text { filter } \\
\text { membrane }\end{array}$ & $\begin{array}{c}\text { Intelligent } \\
\text { TSP } \\
\text { sampler }\end{array}$ & $\begin{array}{l}\text { Weight } \\
\text { method }\end{array}$ \\
\hline Temperature & $\begin{array}{l}\text { Direct } \\
\text { reading }\end{array}$ & $\begin{array}{l}\text { Direct } \\
\text { reading }\end{array}$ & No \\
\hline Air pressure & $\begin{array}{l}\text { Direct } \\
\text { reading }\end{array}$ & $\begin{array}{l}\text { Direct } \\
\text { reading }\end{array}$ & No \\
\hline
\end{tabular}

\subsubsection{Detecting equipment and principle}

The detection method used in this experiment is inductively coupled plasma emission spectrometry, and the detection instrument is inductively coupled plasma emission spectrometer (ICP-OES), so the content of each heavy metal element can be determined.

\subsection{Membrane electric heating plate digestion}

Take a proper amount of filter membrane samples, cut them into small pieces with scissors, put them in a beaker, add $20.0 \mathrm{ml}$ nitric acid-hydrochloric acid mixed digestion solution, immerse the filter membrane fragments in it, cover it with a watch glasses, heat and reflux at $100 \pm 5^{\circ} \mathrm{C}$ for 2 hours, and cool it; Rinse the inner wall of beaker with water, add about $10 \mathrm{ml}$ of water, and let stand for $0.5 \mathrm{~h}$ for leaching; Filter the extract into a $100 \mathrm{ml}$ volumetric flask, and adjust the volume to $100 \mathrm{ml}$ scale with water, to be tested ${ }^{[5]}$. 


\subsection{Wavelength selection}

After igniting the plasma, analyze and compare the intensity, spectrum and interference of each spectral line, and select the best analytical spectral line of each metal element according to the standard HJ777-2015; Introducing the mixed metal standard solution into an emission spectrometer in turn for measurement and establishing a calibration curve; Before analyzing the sample, flush the system with the system washing solution until the blank intensity value is reduced to the minimum, and start analyzing the sample after the analysis signal is stable ${ }^{[5]}$

\subsection{Measurement and analysis}

\subsubsection{The result indicates}

Test results of ICP-OES are shown in tables 4 and 5 .

Table 4. ICP-OES test results of total dust.

\begin{tabular}{cccccccc}
\hline $\begin{array}{c}\text { Sample } \\
\text { number }\end{array}$ & $\begin{array}{c}\mathbf{C u} \\
\left(\boldsymbol{\mu g} / \mathbf{m}^{\mathbf{3}}\right)\end{array}$ & $\begin{array}{c}\mathbf{P b} \\
\left(\boldsymbol{\mu g} / \mathbf{m}^{\mathbf{3}}\right)\end{array}$ & $\begin{array}{c}\mathbf{C d} \\
\left(\boldsymbol{\mu} \mathbf{g} / \mathbf{m}^{\mathbf{3}}\right)\end{array}$ & $\begin{array}{c}\mathbf{Z n} \\
\left(\boldsymbol{\mu g} / \mathbf{m}^{\mathbf{3}}\right)\end{array}$ & $\begin{array}{c}\mathbf{C r} \\
\left(\boldsymbol{\mu g} / \mathbf{m}^{\mathbf{3}}\right)\end{array}$ & $\begin{array}{c}\mathbf{H g} \\
\left(\boldsymbol{\mu g} / \mathbf{m}^{\mathbf{3}}\right)\end{array}$ & $\begin{array}{c}\mathbf{B a} \\
\left(\boldsymbol{\mu g} / \mathbf{m}^{\mathbf{3}}\right)\end{array}$ \\
\hline z-01 & 5.00 & 1.39 & 0.10 & 224.41 & 0.41 & 3.53 & 200.89 \\
z-02 & 7.63 & 22.13 & 0.46 & 318.45 & 0.15 & 1.17 & 204.96 \\
z-03 & 6.09 & 7.94 & 0.15 & 181.31 & 0.39 & 0.92 & 143.41 \\
z-04 & 8.18 & 0.20 & 0.09 & 266.70 & 1.47 & 1.44 & 220.74 \\
z-05 & 3.60 & 0.27 & 0.13 & 372.85 & 1.08 & 1.46 & 86.21 \\
z-06 & 3.89 & 1.37 & 0.06 & 216.64 & 0.95 & 1.24 & 173.84 \\
z-07 & 11.96 & 11.49 & 0.05 & 187.81 & 1.38 & 0.68 & 303.34 \\
z-08 & 1.62 & 1.79 & 0.06 & 661.94 & 0.13 & 4.53 & 137.42 \\
z-09 & 17.29 & 0.81 & 0.10 & 204.78 & 0.13 & 0.50 & 75.27 \\
z-10 & 7.03 & 4.09 & 0.07 & 221.55 & 0.50 & 2.27 & 106.30 \\
Average & 7.23 & 5.15 & 0.13 & 285.64 & 0.66 & 1.77 & 165.24 \\
Average & $1.55 \%$ & $1.11 \%$ & $0.03 \%$ & $61.32 \%$ & $0.14 \%$ & $0.38 \%$ & $35.47 \%$ \\
proportion & & & & & &
\end{tabular}

Table 5. ICP-oes test results of PM10.

\begin{tabular}{cccccccc}
\hline $\begin{array}{c}\text { Sample } \\
\text { number }\end{array}$ & $\begin{array}{c}\mathbf{C u} \\
\left(\boldsymbol{\mu g} / \mathbf{m}^{\mathbf{3}}\right)\end{array}$ & $\begin{array}{c}\mathbf{P b} \\
\left(\boldsymbol{\mu g} / \mathbf{m}^{\mathbf{3}}\right)\end{array}$ & $\begin{array}{c}\mathbf{C d} \\
\left(\boldsymbol{\mu g} / \mathbf{m}^{\mathbf{3}}\right)\end{array}$ & $\begin{array}{c}\mathbf{Z n} \\
\left(\boldsymbol{\mu g} / \mathbf{m}^{\mathbf{3}}\right)\end{array}$ & $\begin{array}{c}\mathbf{C r} \\
\left(\boldsymbol{\mu g} / \mathbf{m}^{\mathbf{3}}\right)\end{array}$ & $\begin{array}{c}\mathbf{H g} \\
\left(\boldsymbol{\mu g} / \mathbf{m}^{\mathbf{3}}\right)\end{array}$ & $\begin{array}{c}\mathbf{B a} \\
\left(\boldsymbol{\mu g} / \mathbf{m}^{\mathbf{3}}\right)\end{array}$ \\
\hline h-01 & 0.35 & 0.37 & 0.08 & 3.28 & 0.09 & 0.07 & 17.65 \\
h-02 & 0.75 & 0.05 & 0.32 & 64.53 & 0.02 & 0.04 & 28.03 \\
h-03 & 0.24 & 0.35 & 0.08 & 86.02 & 0.06 & 0.03 & 0.40 \\
h-04 & 0.43 & 0.01 & 0.04 & 12.12 & 0.02 & 0.04 & 24.21 \\
h-05 & 0.83 & 0.05 & 0.09 & 10.25 & 0.38 & 0.08 & 9.03 \\
h-06 & 0.38 & 0.49 & 0.05 & 33.19 & 0.01 & 0.00 & 8.63 \\
h-07 & 0.93 & 2.14 & 0.04 & 24.83 & 0.03 & 0.04 & 26.64 \\
h-08 & 0.04 & 0.13 & 0.05 & 4.08 & 0.03 & 0.15 & 3.45 \\
h-09 & 1.34 & 0.52 & 0.06 & 27.07 & 0.03 & 0.03 & 1.10 \\
h-10 & 0.04 & 0.20 & 0.06 & 29.60 & 0.05 & 0.04 & 27.56 \\
Average & 0.53 & 0.43 & 0.09 & 29.50 & 0.07 & 0.05 & 14.67 \\
Average & $1.17 \%$ & $0.95 \%$ & $0.20 \%$ & $65.06 \%$ & $0.15 \%$ & $0.11 \%$ & $32.36 \%$ \\
proportion & & & & & &
\end{tabular}

According to the data in Table 5 and Table 6 , by comparing and analyzing the average concentration of total dust and Huchen, it is concluded that the main components of heavy metals in total dust in Xiqing District of Tianjin are $\mathrm{Zn}$ and $\mathrm{Ba}$,among which $\mathrm{Zn}$ is the main one, and its concentration accounts for $61.32 \%$ of the total heavy metal concentration, reaching $285.64 \mu \mathrm{g} / \mathrm{m}^{3}$. The main components of heavy metals in huchen are consistent with the total dust, followed by $\mathrm{Zn}$ and $\mathrm{Ba}$, in which $\mathrm{Zn}$ concentration accounts for $65.06 \%$ of the total heavy metal concentration, reaching $29.50 \mu \mathrm{g} / \mathrm{m}^{3}$.

\subsubsection{Analysis of results}

(1) Analysis of the influence of heavy metal elements on air quality
According to "Ambient Air Quality Standard" (GB3095-2012) ${ }^{[6]}$, the following results can be obtained by analyzing the data in Tables 5 and 6 :

(1) The concentration of $\mathrm{Cd}$ seriously exceeded the standard, reaching $0.13 \mu \mathrm{g} / \mathrm{m}^{3}$ in total dust and $0.09 \mu \mathrm{g} / \mathrm{m}^{3}$ in respirable dust, far exceeding the limit value of $0.005 \mu \mathrm{g} / \mathrm{m}^{3}$.

(2) $\mathrm{Hg}$ concentration exceeds the standard, reaching $1.77 \mu \mathrm{g} / \mathrm{m}^{3}$ in total dust and $0.05 \mu \mathrm{g} / \mathrm{m}^{3}$ in respirable dust, with a limit of $0.05 \mu \mathrm{g} / \mathrm{m}^{3}$.

(3) $\mathrm{Pb}$ concentration exceeds the standard, reaching $5.15 \mu \mathrm{g} / \mathrm{m}^{3}$ in total dust and $0.43 \mu \mathrm{g} / \mathrm{m}^{3}$ in respirable dust, with a limit of $0.5 \mu \mathrm{g} / \mathrm{m}^{3}$.

(4) $\mathrm{Cr}$ concentration slightly exceeded the standard, reaching $0.66 \mu \mathrm{g} / \mathrm{m}^{3}$ in total dust and $0.07 \mu \mathrm{g} / \mathrm{m}^{3}$ in respirable dust, with a limit of $0.05 \mu \mathrm{g} / \mathrm{m}^{3}$. 
(5) $\mathrm{Cu}$ concentration exceeded the standard, reaching $7.23 \mu \mathrm{g} / \mathrm{m}^{3}$ in total dust and $0.53 \mu \mathrm{g} / \mathrm{m}^{3}$ in respirable dust, with a limit of $0.253 \mu \mathrm{g} / \mathrm{m}^{3}$.

(6) The $\mathrm{Zn}$ concentration seriously exceeded the standard, reaching $285.64 \mu \mathrm{g} / \mathrm{m}^{3}$ in total dust and $29.5 \mu \mathrm{g} / \mathrm{m}^{3}$ in respirable dust, with a limit of $0.232 \mu \mathrm{g} / \mathrm{m}^{3}$.

(7) Ba concentration seriously exceeded the standard, reaching $165.24 \mu \mathrm{g} / \mathrm{m}^{3}$ in total dust and $14.67 \mu \mathrm{g} / \mathrm{m}^{3}$ in respirable dust, with a limit of $2.13 \mu \mathrm{g} / \mathrm{m}^{3}$.

According to the above data, the air quality in Xiqing District of Tianjin is poor.

(2) Analysis of the influence of heavy metal elements on human health

According to the data in Tables 4 and 5, the concentration distribution of heavy metals can be obtained, and the results are shown in Table 6 .

Table 6. Heavy metal concentration distribution.

\begin{tabular}{|c|c|c|c|c|c|c|c|}
\hline $\begin{array}{c}\text { Sample } \\
\text { Numbering }\end{array}$ & $\mathbf{C u}$ & $\mathbf{P b}$ & Cd & Zn & $\mathrm{Cr}$ & Hg & $\mathbf{B a}$ \\
\hline 01 & $7.07 \%$ & $26.61 \%$ & $87.14 \%$ & $1.46 \%$ & $22.18 \%$ & $2.00 \%$ & $8.78 \%$ \\
\hline 02 & $9.79 \%$ & $0.21 \%$ & $70.29 \%$ & $20.26 \%$ & $15.09 \%$ & $3.33 \%$ & $13.68 \%$ \\
\hline 03 & $3.92 \%$ & $4.41 \%$ & $57.18 \%$ & $47.44 \%$ & $15.09 \%$ & $2.86 \%$ & $0.28 \%$ \\
\hline 04 & $5.29 \%$ & $5.65 \%$ & $43.62 \%$ & $4.54 \%$ & $1.61 \%$ & $2.58 \%$ & $10.97 \%$ \\
\hline 05 & $23.0 \%$ & $18.59 \%$ & $70.29 \%$ & $2.75 \%$ & $35.63 \%$ & $5.60 \%$ & $10.47 \%$ \\
\hline 06 & $9.68 \%$ & $35.76 \%$ & $77.47 \%$ & $15.32 \%$ & $1.00 \%$ & $0.33 \%$ & $4.97 \%$ \\
\hline 07 & $7.73 \%$ & $18.59 \%$ & $77.91 \%$ & $13.22 \%$ & $2.29 \%$ & $5.74 \%$ & $8.78 \%$ \\
\hline 08 & $2.62 \%$ & $7.02 \%$ & $75.14 \%$ & $0.62 \%$ & $22.39 \%$ & $3.33 \%$ & $2.51 \%$ \\
\hline 09 & $7.73 \%$ & $64.21 \%$ & $56.87 \%$ & $13.22 \%$ & $24.76 \%$ & $5.88 \%$ & $1.47 \%$ \\
\hline 10 & $0.50 \%$ & $4.87 \%$ & $86.99 \%$ & $13.36 \%$ & $10.83 \%$ & $1.63 \%$ & $25.93 \%$ \\
\hline Average & $7.73 \%$ & $18.59 \%$ & $70.29 \%$ & $13.22 \%$ & $15.09 \%$ & $3.33 \%$ & $8.78 \%$ \\
\hline
\end{tabular}

From the data analysis in Table 6 , the following results can be obtained:

(1) The particle size distribution of $\mathrm{Cd}$ in dust in Xiqing District of Tianjin is mainly below $7.07 \mu \mathrm{m}$, and the concentration ratio of respirable dust to total dust is $70.29 \%$. Data show that the respiratory tract is the main channel for Cd exceeding the standard in Tianjin. Cd is not easily absorbed by intestinal tract, but absorbed by body through breathing, so the particle size distribution of $\mathrm{Cd}$ in the atmosphere is harmful to human body.

(2) The particle size distribution of $\mathrm{Hg}$ is mainly over $7.07 \mu \mathrm{m}$, and the concentration ratio of respirable dust to total dust is only $3.33 \%$. The data show that the main channel of $\mathrm{Hg}$ contact with human body in Tianjin atmosphere is skin contact. Mercury is easily absorbed by skin, respiratory tract and digestive tract, so the particle size distribution of $\mathrm{Hg}$ in the atmosphere is harmful to human body.

\section{Conclusion}

After sampling PM10 and total dust in the campus atmosphere for 10 consecutive days in autumn, the following conclusions are drawn:

(1) The concentrations of seven heavy metal elements $\mathrm{Cu}, \mathrm{Pb}, \mathrm{Cd}, \mathrm{Zn}, \mathrm{Cr}, \mathrm{Hg}$ and $\mathrm{Ba}$ in the atmosphere of Xiqing District of Tianjin were measured by experiments, among which $\mathrm{Zn}$ was the highest, followed by $\mathrm{Ba}$, so the heavy metal pollutants in the atmosphere were mainly $\mathrm{Zn}$ and $\mathrm{Ba}$.

(2) The concentrations of $\mathrm{Cd}, \mathrm{Hg}$ and $\mathrm{Pb}$ seriously exceed the standard, while the concentrations of $\mathrm{Cu}, \mathrm{Pb}$, $\mathrm{Cr}$ and $\mathrm{Hg}$ exceed the standard, so the air quality in Xiqing District of Tianjin is poor, and the particle size distribution of $\mathrm{Cd}$ and $\mathrm{Hg}$ makes it easy to enter the human body, which is especially unfavorable to human health.

\section{Acknowledgement}

This work was sponsored in part by Tianjin Science and technology major special projects and engineering projects (18ZXSZSF00090),Ministry of Education Humanities and Social Sciences Research Planning Fund (18YJA630121), Tianjin Key R\&D Plan Achievements Transformation Relay Support Project (18YFJLCG00140), Tianjin Municipal Education Commission Social Science Major Project (2018JWZD33), Tianjin Science and Technology Major Special Project and Engineering Project (17ZXSTSF00020), Research and development and system integration application of "Internet +" sudden water environmental safety accident monitoring and early warning technology (19JCTPJC57100), Tianjin "Project + Team" key training special project (BIM-based digital twin building intelligent simulation and operation and maintenance management), Qingdao City Yang Industrial Park supports the creation of characteristic carriers to promote small and medium-sized enterprises innovation and entrepreneurship upgrading projects (Qingdao Rail Transit Intelligent Green Simulation and Digital Simulation Center).

\section{References}

1. X.Y Li, H.Z Lian, Y.J Chen, et al. Spectroscopy and Spectral Analysis, ,9 2181-2186 (2008): .

2. J.R Tang, J.P Lu, Z.F Tong, Environmental Science and Technology, 5 126-128 ( 2010) .

3. X Liu, Environmental Chemistry, 6 741-743 (2005).

4. Z.L Chen. Spectroscopy and Spectral Analysis, 5 601- 
605 (1998)

5. Determination of metal elements in air and exhaust gas particulate matter.HJ777-2015 (2015).

6. Ambient air quality standard .GB3095-2012 (2012). 